\title{
EVALUATION OF MICROTEXTURE CHANGES OF COARSE AGGREGATE DURING SIMULATED POLISHING
}

\author{
W. GARDZIEJCZYK ${ }^{1}$, M. WASILEWSKA ${ }^{2}$
}

\begin{abstract}
This paper presents application of optical microscope for evaluation of microtexture changes of coarse aggregate during simulated polishing in laboratory. Observations of the apparent changes on surfaces of seven different aggregates are presented. Simulation polishing of aggregate was performed in accordance with PN-EN 10978:2009. Images of the aggregate surface were taken with the optical microscope in the reflection mode in particular stages of polishing. Digital images were analyzed. Standard deviation was determined on the basis of the histogram of intensities from digital images of the surfaces of aggregate grains which was assumed as the measure of changes in microtexture during simulated polishing (namely the $\sigma_{h}$ parameter). Statistical analysis has shown that the changes of the $\sigma_{h}$ parameter between the particular stages of polishing confirm certain trends related to the petrographic characteristic of the rocks. Aggregates which included minerals of similar hardness (granodiorite, dolomite, basalt) were more prone to polishing than gabbro and postglacial. Regeneration of the microtexture, the recovery to its original asperity, occurred in the case of quartz sandstone and steelmaking slag.
\end{abstract}

Keywords: coarse aggregate, microtexture, image analysis, histogram of intensities, PSV

\section{INTRODUCTION}

Skid resistance plays an important role in reducing road accidents in wet conditions. Especially macrotexture and microtexture influence skid resistance [6]. Macrotexture depends on asphalt mixture properties (size and gradation of aggregate) or the texturing method used on concrete pavement surfaces. Macrotexture has an effect on skid resistance especially at high vehicle speed. Microtexture depends on polishing resistance of coarse aggregate in wearing course. In actual traffic conditions the phenomenon of polishing which affects the protruding aggregate grains is caused by tires, pollution and water. This process as a result leads to pavement slipperiness.

\footnotetext{
${ }^{1} \mathrm{PhD}$, DSc, Eng, Univ. Professor, Faculty of Civil and Environment Engineering, Bialystok University of Technology, Bialystok, Poland, e-mail: w.gardziejczyk@pb.edu.pl (corresponding author)

${ }^{2} \mathrm{PhD}$, Faculty of Civil and Environment Engineering, Bialystok University of Technology, Bialystok, Poland, e-mail: marta.wasilewska@pb.edu.pl
} 
During the process of polishing the surface of aggregate undergoes changes depending on the petrographic content, hardness of minerals, texture, structure, porosity and the extent of rock weathering.

In Poland, the resistance to polishing of coarse aggregates used for the wearing course is quantified by the PSV (Polished Stone Value) according to the standard PN-EN 1097-8:2009. The resistance to polishing of seven different aggregates were conducted. Specimens of aggregates and specimens of control stone were clamped round the periphery of the road wheel of polishing machine and were brought to the speed of $315 \mathrm{rev} / \mathrm{min}$. The outer surface of the specimen form a continuous strip, upon which rubber tire rode freely and moved without bumping or slipping. Test lasted 6 hours and consisted of two three-hour stages. In the $1^{\text {st }}$ stage water and corn emery were fed continuously on to the road wheel and in the $2^{\text {nd }}$ stage water and emery flour were fed. $S$ friction coefficient measured with portable Skid Resistance Tester (namely the British Pendulum Tester) was made before polishing $\left(0 \mathrm{~h}\right.$ ), after the $1^{\text {st }}$ stage (after $3 \mathrm{~h}$ ) and after the $2^{\text {nd }}$ stage of polishing (after $6 \mathrm{~h}$ ). $S$ friction coefficient is calculated from the measurement of kinetic energy loss when the rubber slider is dragged on the wet specimen surface.

The $P S V$ was calculated after $2^{\text {nd }}$ stage of polishing with consideration for both mean values $S$ obtained for four aggregates specimens and mean values $S$ obtained for control stone specimens. Therefore for the presentation of the results during the polishing process $S$ values were used. The $P S V$ and $S$ values with their standard deviation $(S T D)$ in particular stages are presented in Table 1. Aggregates ranking for resistance to polishing based on $S$ values is shown in Fig. 1 before polishing and after $2^{\text {nd }}$ stage.

Before polishing $S$ was high (above 70). A significant decrease of $S$ was registered at the end of the process. The lowest values of $S$ were obtained for dolomite, granodiorite and basalt. Quartz sandstone was characterized by the highest $S$ value. Steelmaking slag, gabbro and postglacial performed well during the polishing resistance test too. Based on the results (Table 1 and Fig. 1) it was discovered that the type of rocks had a different degree of sensitivity to polishing during particular stages of this process. It should be noted that under actual conditions on roads both polishing and abrasion take place. Therefore the use of test procedure according the standard PNEN 1097-8:2009 allows evaluating changes of aggregates surface under the influence of two different abrasives. In the $1^{\text {st }}$ stage of the test by applying the coarse emery and water the phenomenon of abrasion were simulated and in the $2^{\text {nd }}$ stage the emery flour and water were used for polishing. 
Table 1. Results of the $P S V$ and $S$ values and standard deviation

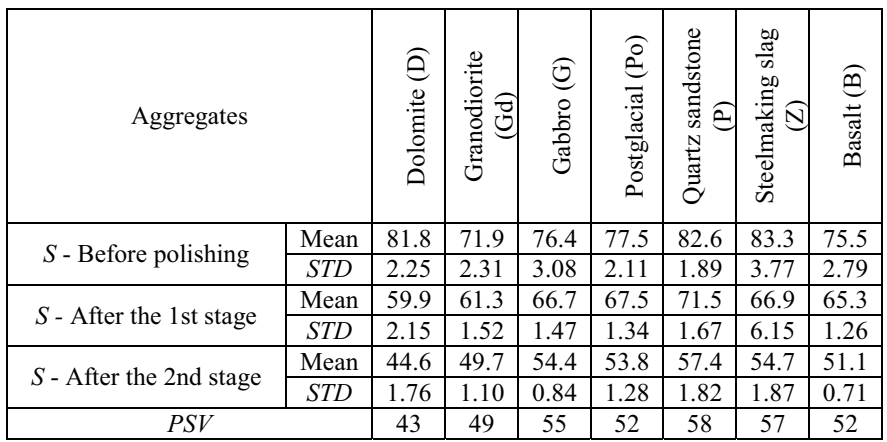

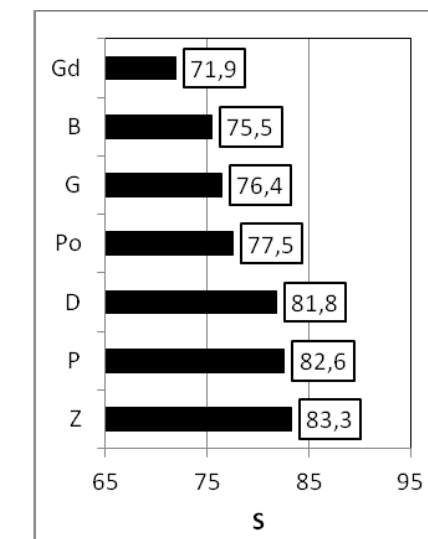

a)

Fig. 1. Aggregates ranking for resistance to polishing based on $S$ values a) before polishing

In Poland, according to the requirements for the wearing course subjected to heavy traffic coarse aggregates with their $P S V \geq 50$ (asphalt pavements), $P S V \geq 53$ (concrete pavements) can be applied. It should be noted there are not many aggregate deposits which satisfy both PSV and another physical properties. Aggregates with high PSV are recommended for locations especially exposed to slippery conditions such as intersections, crossroads, roundabouts, junctions etc. That is why such aggregates should be rationally used in road construction.

However, it is hard to explain phenomena which occurs on the grain surface based only on $S$ or PSV results. This requires insight into the phenomena which occurs on the surface of the particular grains. It means the thorough knowledge of the polishing process related to the aggregates made from rocks with different origin and petrographic characteristics is indispensable. 
One of the theories of polishing (the wear-deformation theory) mentions wearing of microscopic protrusions on the surface of grains as a result of abrasion caused by car tires combined with spatial deformation of crystalline structure of minerals [8]. Dahir and Mulle explained the phenomenon of polishing of stone materials on the basis of the content of minerals in the rock and their hardness. Toureng and Fourmaintraux proved that the presence of minerals of varied hardness in the rock results in varied microtexture of grain surface and greater resistance to polishing [1, 12]. In France a model was developed which describes skid resistance to get a better understanding of the influence of the polishing process on the evolution of surface texture. The model was based on the description of geometry of microtexture on the grain surface $[2,3]$. In other studies the analyses of microtexture were conducted on the basis of microscope images of aggregate [5, 10, 14]. Dunford et al. showed that the use of three-dimensional surface measurement of aggregate profile ensures accurate analysis of changes in microtexture of aggregates in the polishing process [4].

The advances in opto-electronic and computer technology were accompanied by the advances of surface analysis based on the computer processing of digital images. Many methods are applied in fields such as metallography, crystallography, tribology, geology, medicine $[7,13,15]$. In the last decades the image analysis method has been often used to characterize the morphology of coarse aggregates $[4,5,16]$.

In this paper the possibility of using digital images for understanding reasons of changes occurring on grain surface of aggregates in polishing process is presented.

\section{Program Research}

Images of the aggregate surface were taken with the optical microscope in the reflection mode before polishing $(0 \mathrm{~h})$, after the $1^{\text {st }}$ stage (after $3 \mathrm{~h}$ ) and after the $2^{\text {nd }}$ stage of polishing (after $6 \mathrm{~h}$ ). Dolomite, granodiorite, gabbro, postglacial, quartz sandstone, steelmaking slag and basalt were taken for investigation. The results of $S$ values and $P S V$ were previously presented (Table 1). Four specimens of each aggregate were prepared. Polishing process was simulated according to the standard PN-EN 1097-8:2009 [17]. The 30 images (3.2 x magnifications) from randomly selected locations were taken for each of the specimen. Specimen surfaces were registered using a CCD camera under controlled lighting conditions.

The images of aggregates from the optical microscope are raster images having a finite set of digital values, called pixels. Each image contains a fixed number of rows and columns of pixels. Such image may be subject to digital image processing. Primary goal of this processing is to improve its 
visual quality and obtain quantitative information (image analysis). Image analysis involves the determination of numerical descriptors calculated on the basis of various statistical characteristics for a set of pixels that make up digital images. Modern technology includes many tools for image processing and analysis. Most descriptions are used by a statistical method. Each of the pixels in an image holds quantized values which represent the brightness of a given grey level at any specific point. A statistical distribution of brightness of pixels is described as a histogram of intensities. This histogram is a graph showing the number of pixels in an image at each different intensity value found in that image. In our case the image was saved in an 8-bit grayscale image. They were characterized by 256 different possible intensities, and so the histogram graphically displayed 256 numbers showing the distribution of pixels amongst those grayscale values. Grayscale variations represent local surface-relief variations. The value of the $\sigma_{h}$ parameter from the histogram of intensities was assumed as a measure of microtexture (Fig. 2).

\section{RESULTS AND ANALYSIS}

Median, the lower and the upper quartile, minimum and maximum calculated by the given data set of the $\sigma_{\mathrm{h}}$ parameter of particular aggregates were presented in Fig 3.

Non-parametric Friedman test was used to check if on the accepted significance level $\alpha=0,05$ significant differences between mean of the $\sigma_{h}$ parameter registered for the given aggregate in the polishing stages have occured. The results are presented in Table 2.

In the case of dolomite, granodiorite, gabbro, postglacial, steelmaking slag, basalt $p=0.00$ is lower than the chosen significance level $\alpha=0.05$. It means that there is a statistically significant difference between the $\sigma_{h}$ parameter on the particular stages of polishing. There are no basis to reject the $H_{0}$ hypothesis only for quartz sandstone $(p=0.08)$.

The highest the $\sigma_{h}$ parameter before polishing had holocrystaline aggregates (gabbro and granodiorite), the lowest - steelmaking slag and hypocrystaline (basalt). Images analyzed showed that irregularities on the surface which resulted from natural fracture, which is typical for the given rock type (Fig. 4, Fig. 5). Percentage change of the $\sigma_{h}$ parameter between the particular stages of polishing show certain trends related to the petrographic characteristics of the material (Table 3). 


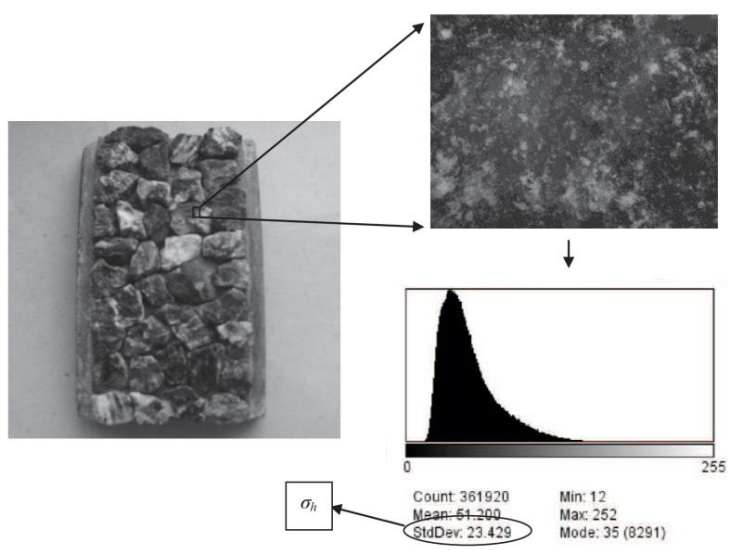

Fig. 2. Exemplary specimen of the aggregate (gabbro), its surface digital image and its grey level histogram
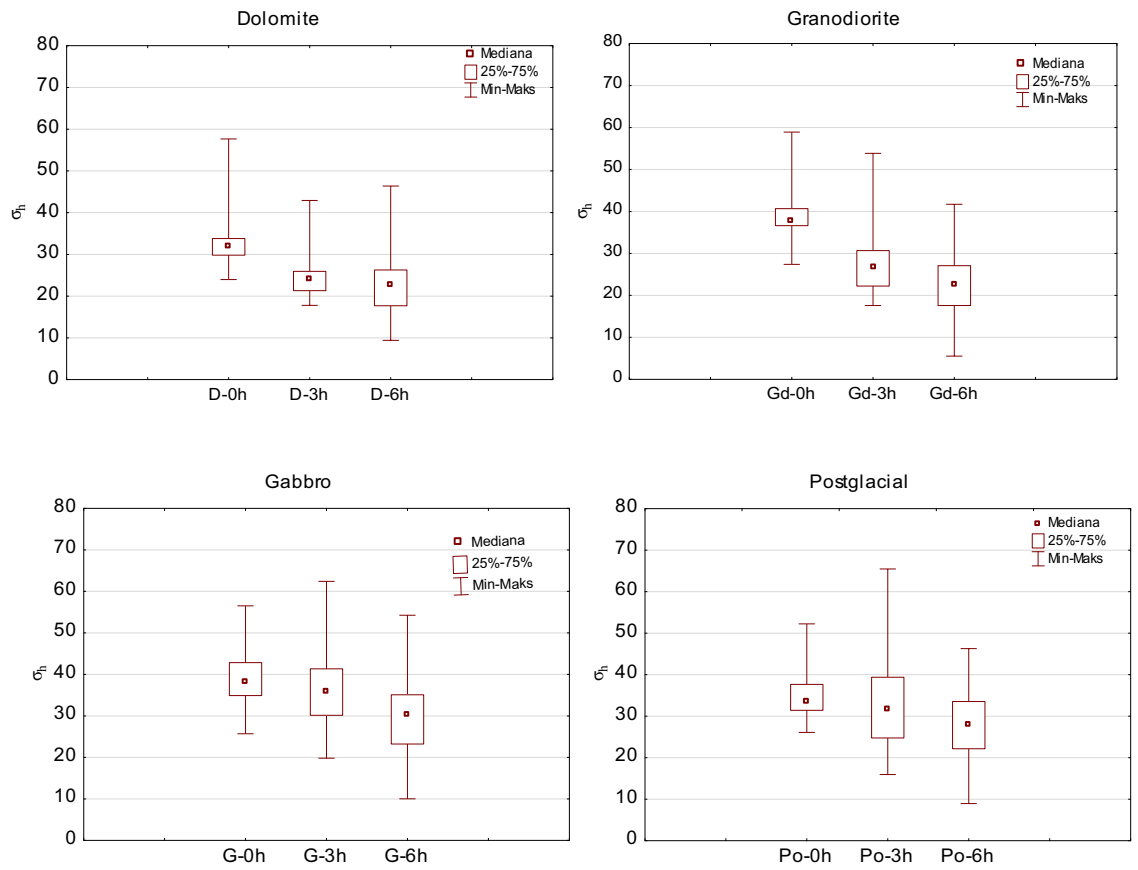

Fig. 3. Summary statistics in particular stages of polishing 

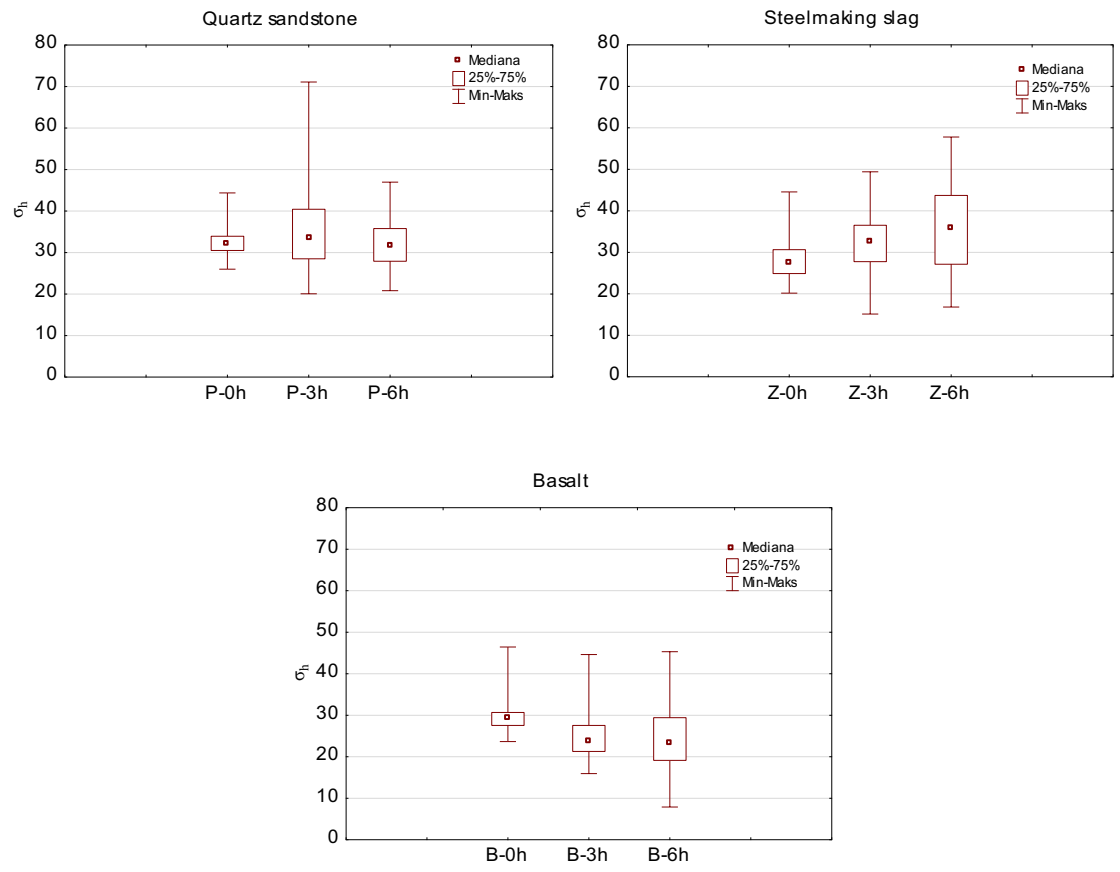

Fig. 3. Summary statistics in particular stages of polishing - continued

Table 2. Friedman test results

\begin{tabular}{|c|c|c|c|c|c|c|}
\hline Stage: & $\begin{array}{c}\text { Mean } \\
\text { rank }\end{array}$ & $\begin{array}{l}\text { Rank } \\
\text { sums }\end{array}$ & $\begin{array}{c}\text { Mean } \\
\text { the } \sigma_{h} \\
\text { parameter }\end{array}$ & $S T D$ & $\begin{array}{c}\chi^{2} \\
\text { ANOVA } \\
(2 ; 120)\end{array}$ & $p$ \\
\hline \multicolumn{7}{|c|}{ Dolomite } \\
\hline Before polishing & 2.91 & 349.00 & 32.09 & 3.99 & \multirow{3}{*}{149.72} & \multirow{3}{*}{0.00} \\
\hline After the 1st stage & 1.62 & 194.00 & 24.29 & 4.10 & & \\
\hline After the 2nd stage & 1.48 & 177.00 & 22.55 & 6.71 & & \\
\hline \multicolumn{7}{|c|}{ Granodiorite } \\
\hline Before polishing & 2.85 & 342.00 & 38.24 & 3.78 & \multirow{3}{*}{137.40} & \multirow{3}{*}{0.00} \\
\hline After the 1st stage & 1.75 & 210.00 & 27.89 & 7.87 & & \\
\hline After the 2nd stage & 1.40 & 168.00 & 23.09 & 7.39 & & \\
\hline \multicolumn{7}{|c|}{ Gabbro } \\
\hline Before polishing & 2.42 & 290.00 & 38.95 & 5.85 & \multirow{3}{*}{54.07} & \multirow{3}{*}{0.00} \\
\hline After the 1st stage & 2.10 & 252.00 & 3701 & 9.39 & & \\
\hline After the 2nd stage & 1.48 & 178.00 & 29.82 & 8.57 & & \\
\hline \multicolumn{7}{|c|}{ Postglacial } \\
\hline Before polishing & 2.29 & 275.00 & 34.53 & 4.55 & \multirow{3}{*}{26.15} & \multirow{3}{*}{0.00} \\
\hline After the 1st stage & 2.07 & 248.00 & 32.74 & 9.78 & & \\
\hline After the 2nd stage & 1.64 & 197.00 & 28.31 & 7.45 & & \\
\hline
\end{tabular}


Table 2. Friedman test results - continued

\begin{tabular}{|c|c|c|c|c|c|c|}
\hline Stage: & $\begin{array}{c}\text { Mean } \\
\text { rank }\end{array}$ & $\begin{array}{l}\text { Rank } \\
\text { sums }\end{array}$ & $\begin{array}{c}\text { Mean } \\
\text { the } \sigma_{h} \\
\text { parameter }\end{array}$ & $S T D$ & $\begin{array}{c}\chi^{2} \\
\text { ANOVA } \\
(2 ; 120)\end{array}$ & $p$ \\
\hline \multicolumn{7}{|c|}{ Quartz sandstone } \\
\hline Before polishing & 1.98 & 238.00 & 32.48 & 2.88 & \multirow{3}{*}{4.87} & \multirow{3}{*}{0.08} \\
\hline After the 1st stage & 2.15 & 258.00 & 35.14 & 10.25 & & \\
\hline After the 2nd stage & 1.87 & 224.00 & 31.56 & 5.23 & & \\
\hline \multicolumn{7}{|c|}{ Steelmaking slag } \\
\hline Before polishing & 1.64 & 197.00 & 28.36 & 4.67 & \multirow{3}{*}{27.12} & \multirow{3}{*}{0.00} \\
\hline After the 1st stage & 2.05 & 246.00 & 31.85 & 6.81 & & \\
\hline After the 2nd stage & 2.31 & 277.00 & 35.51 & 10.26 & & \\
\hline \multicolumn{7}{|c|}{ Basalt } \\
\hline Before polishing & 2.49 & 299.00 & 29.54 & 3.27 & \multirow{3}{*}{43.52} & \multirow{3}{*}{0.00} \\
\hline After the 1st stage & 1.75 & 210.00 & 25.27 & 5.78 & & \\
\hline After the 2nd stage & 1.76 & 211.00 & 24.24 & 7.22 & & \\
\hline
\end{tabular}

Table 3. Percentage change of mean values of the $\sigma_{h}$ parameter in particular stages of polishing

\begin{tabular}{|c|c|c|c|}
\hline Aggregate & $\begin{array}{c}\text { Between before } \\
\text { polishing and } 1^{\text {st }} \text { stage }\end{array}$ & $\begin{array}{c}\text { Between the } 1^{\text {at }} \text { and } 2^{\text {nd }} \\
\text { stage }\end{array}$ & $\begin{array}{c}\text { Between before } \\
\text { polishing and }{ }^{2 \text { nd }} \text { stage }\end{array}$ \\
\hline Dolomite & 24.3 & 8.2 & 29.7 \\
\hline Granodiorite & 27.1 & 17.2 & 39.6 \\
\hline Gabbro & 50 & 19.4 & 23.4 \\
\hline Postglacial & 5.2 & 13.5 & 18.0 \\
\hline Quartz sandstone & -8.2 & 10.2 & 2.8 \\
\hline Steelmaking slag & -12.3 & -11.5 & -25.2 \\
\hline Basalt & 14.5 & 4.1 & 17.9 \\
\hline
\end{tabular}

The highest decrease of the $\sigma_{\mathrm{h}}$ parameter after $1^{\text {st }}$ stage was registered for dolomite, granodiorite and basalt. It testifies that they are more prone to polishing in the $1^{\text {st }}$ stage which favors abrasion of the surface more than in the $2^{\text {st }}$ stage conditions. This behavior is typical particularly for monomineral rock (dolomite and basalt) and aggregate built from minerals with similar hardness (granodiorite). On the basis of observations of images from these aggregates it was noticed that the grain surfaces were polished and edges of some minerals changed their original appearance (Fig. 6). In the case of gabbro and postglacial the slight decrease of the $\sigma_{h}$ parameter after the $1^{\text {st }}$ stage indicates that a process of abrasion of microscopic protrusions and slight changes in the crystalline structure of the surface occur. Typical matte (without gloss) appearance was observed on their surface (Fig. 7). Postglacial aggregate is composed of $60 \%$ igneous and metamorphic rocks (granite, gneiss, granodiorite) and of $40 \%$ sedimentary rocks (sandstones, limestones and dolomites) which results in different susceptibility to polishing factors.

Basalt and dolomite are aggregates which are easier to polish and probably their surface was polished as a result of big differences in crystalline structure - very gloss surface (Fig. 8), as early 
as in the $1^{\text {st }}$ stage of polishing. In the $2^{\text {nd }}$ stage, when fine emery was used, not many changes occurred. In the $2^{\text {nd }}$ stage the highest changes in the values of the $\sigma_{h}$ parameter were noted for aggregates on the surface of which process of abrasion in the $1^{\text {st }}$ stage (gabbro, postglacial) underwent. Surface of two holocrystaline rocks (gabbro and granodioryte) were compared. Granodiorite had glossy surface which means that material is very prone to polishing. But only some parts of gabbro surface were glossy (Fig. 9).

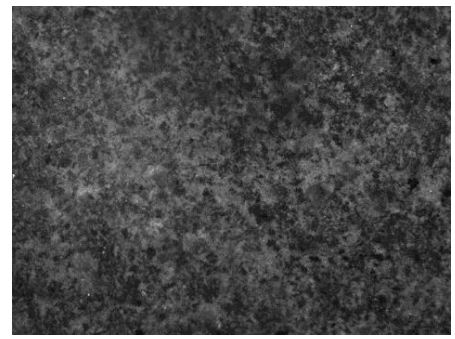

Fig. 4. Dolomite before polishing

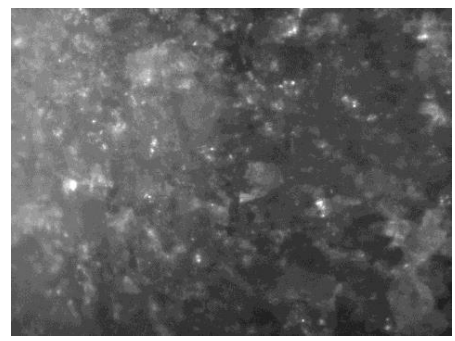

Fig. 6. Dolomite after $1^{\text {st }}$ polishing

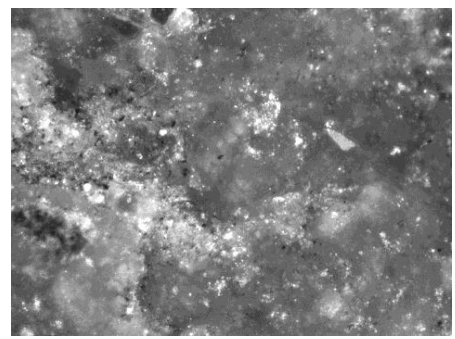

Fig. 8. Dolomite after $2^{\text {nd }}$ Polishing

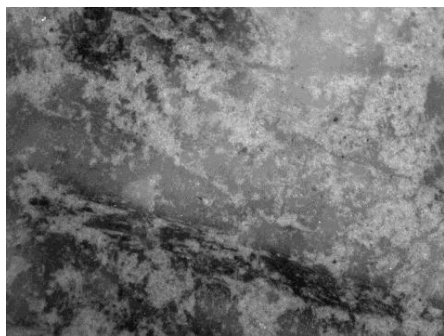

Fig. 5. Gabbro before polishing

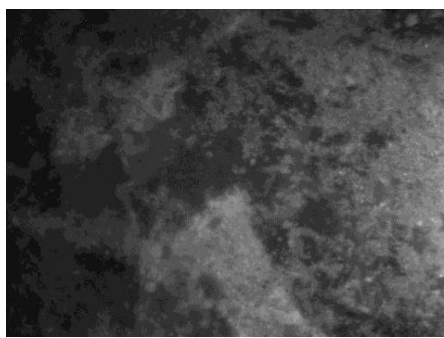

Fig. 7. Gabbro after $1^{\text {st }}$ polishing

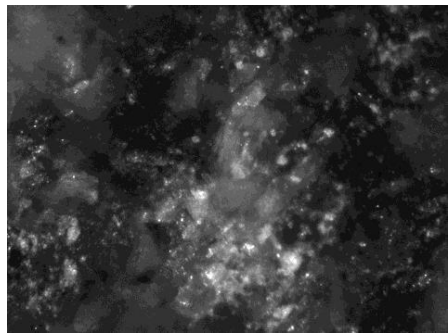

Fig. 9. Gabbro after $2^{\text {nd }}$ polishing 
When dolomite, gronodiorite, gabbro, postglacial, basalt were tested decrease of the $\sigma_{h}$ parameter was registered steelmaking slag and quartz sandstone behaved otherwise.

The surface of quartz sandstone grains acted differently. In the case of this material the images indicate that polishing occurs only on the surface of quartz grains after the $2^{\text {nd }}$ stage. The $1^{\text {st }}$ stage extraction of quartz grains from soft mastic occurred. It was followed by regeneration in $2^{\text {nd }}$ stage (Fig. 10). However, in the $2^{\text {nd }}$ stage polishing affected only the surfaces of quartz grains (Fig. 11). This confirms that changes which result from wearing of microscopic protrusions occur on their surface.

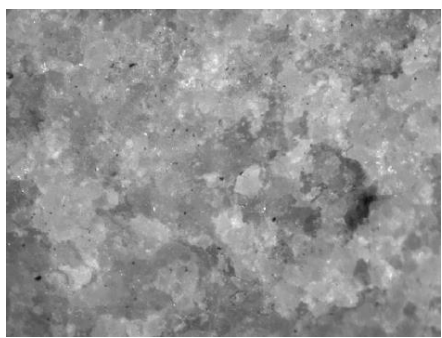

Fig. 10. Quartz sandstone before polishing

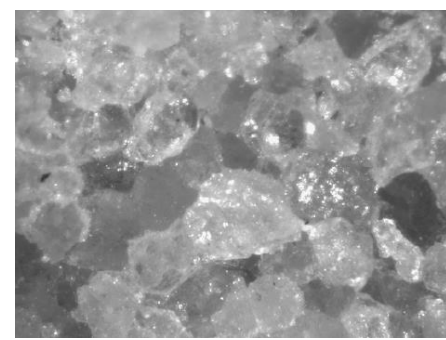

Fig. 11. Quartz sandstone after the $2^{\text {st }}$ stage

In case of the aggregate grains from steelmaking slag there was no decrease of the $\sigma_{\mathrm{h}}$ parameter neither after the $1^{\text {st }}$ nor after the $2^{\text {nd }}$ stage of polishing. It means that the microtexture underwent regeneration after polishing. The surfaces of steelmaking slag grains after polishing displayed the features of polished surface, with its typical gloss and they also resembled surfaces before starting the process of polishing. Some aggregate grains displayed smooth surface during polishing, while after the following hours of polishing the same grains displayed significant roughness (Fig.12-15).

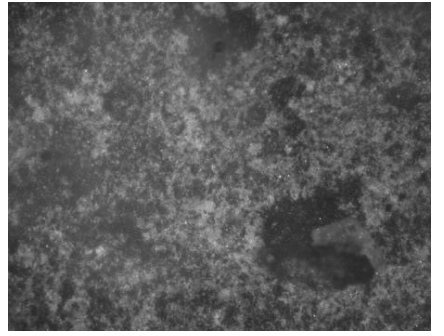

Fig. 12. Steelmaking slag before polishing - smooth surface

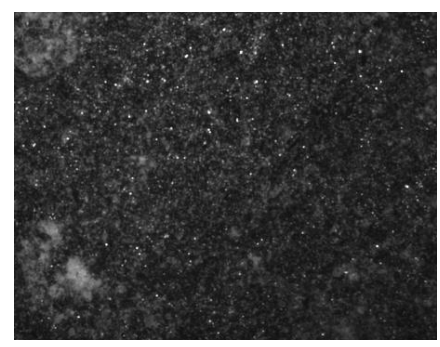

Fig. 13. Steelmaking slag before polishing - roughness surface 


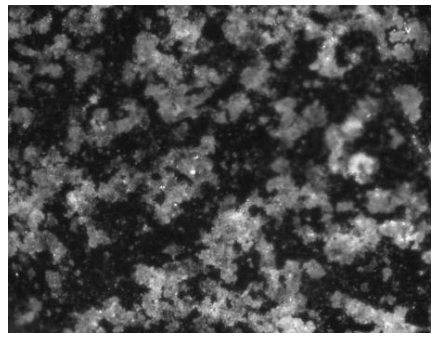

Fig. 14. Steelmaking slag after the $2^{\text {st }}$ stage - smooth surface with gloss

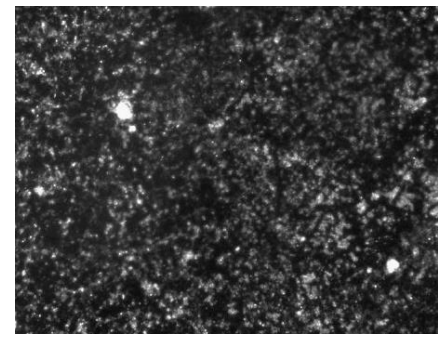

Fig. 15. Steelmaking slag after the $2^{\text {st }}$ stage - roughness surface

The results of the analysis are consistent with some theoretical types of polish resistance which were proposed by Hosking [8]. On this basis it may be stated that the low polishing resistance of dolomite, granodiorite, basalt is due to the mineral composition minerals with similar hardness. Gabbro and postglacial are composed of different minerals and they are more resistant to polishing. Hosking also describes aggregates with high polishing resistance, these porous materials like steelmaking slag or with sandstorm structure of rocks like sandstone. But only microscope images allow proving that these rocks have the additional ability to regeneration their microtexture.

\section{Conclusions}

The investigations of resistance to polishing were conducted on seven aggregates. On the basis of non-parameter Friedman significance test it was found that the $\sigma_{h}$ parameter determined on the basis of the histogram of intensities from digital images can be used to describe the changes of microtexture in the process of polishing.

The analysis of the $\sigma_{h}$ parameter shows a diverse course of the changes on microtexture of aggregate depending on its type. Aggregates which included minerals of similar hardness (granodiorite, dolomite, basalt) are prone to polishing. Gabbro, postglacial and quartz sandstone are the best aggregates for wearing course. It should be note that different character of changes occurring on the surface of grains from steelmaking slag in comparison with the surface of natural aggregates. Image analysis showed that the aggregates tend to regenerate the microtexture.

It is very important information considering shortage of high PSV aggregates. Such aggregates as steelmaking slag or quartz sandstone should be built in road sections particularly subjected to polishing. 


\section{ACKNOWLEDGEMENT}

We would like to express our appreciation to Prof. Maria Tekielak from University of Bialystok for many helpful suggestions.

\section{REFERENCES}

1. M-T. Do, "Relation entre la microtexture et l'adherence. Adhérence - Numéro spécial 254", Bulletin des Laboratoires des Points et Chaussées, Avril - Mai - Juin, France, 2005.

2. M-T. Do, M. Kane, Z. Tang, F. Larrard, "Physical model for the prediction of pavement polishing", Wear 267:81-85, 2009.

3. M-T. Do, Z. Tang, F. Larrard, "Evolution of road-surface skid-resistance and texture due to polishing". Wear 266: 574-577, 2009.

4. A.M. Dunford, A.R. Parry, P.H. Shipway, H.E. Viner, "Three-dimensional characterization of surface texture for road stones undergoing simulated traffic wear", Wear 292-293:188-196, 2012.

5 W. Gutt, P. Nixon, "Studies of the texture of some road stone materials by scanning electron", J Mater Sci 7: 995-1002, 1989

6. J.W. Hall, K.L. Smith, L.Titus-Glover, J.C. Wambold, T.J. Yager, Z. Rado, "Guide for pavement friction. NCHRP Web-only document 108”. Contractor's Final Report NCHRP Project 01-43, 2009.

7. O. Holub, S.T.Ferreira, "Quantitative histogram analysis of images", Computer Physics Communications 175: 620-623, 2006.

8. P.G. Roe, S.A. Hartshorne, "The Polished Stone Value of aggregates and in-service skidding resistance" TRL Report 322. Crowthorne,1998.

9. P.G. Roe, A. Parry, H.E. Viner, "High and low speed skidding resistance the influence of texture depth" TRL Report 367. Crowthorne, 1998.

10. A.B. Slimane, Khoudeir, J. Brochard, M-T. Do, "Characterization of road microtexture by means of image analysis", Wear 264: 464-468, 2008

11. D.J. Sheskin, "Parametric and nonparametric statistical procedures", CRC Boca Raton; 1996.

12. A.R.G. Van de Wall, "The polishing of aggregate used in road construction. The relation between the Polished Stone Value and the petrography and mechanic properties of road aggregate". Faculty of Mining and Petroleum Engineering, Section of Engineering Geology. No 96, T.U. Delft,1992.

13. J.L. Vilaca, J.C. Fonseca, A.C.M. Pinho, E. Freitas, “3D profile equipment for the characterization of the pavement texture - TexScan”, Mechatronics 20: 674-685, 2010.

14. M. Wasilewska, W. Gardziejczyk, "Analiza ilościowa i jakościowa zmian mikroteksturalnych powierzchni kruszywa stosowanego do warstwy ścieralnej” Zesz. Nauk. PRzesz. Bud. i Inż. Środ Z. 59-cz.4: 361-368, 2012 .

15. A. Zawada-Tomkiewicz "Machined surface image analysis for the estimation of the surface parameters", Acta Mechanica et Automatica 1:79-89, 2007.

16. D. Zhang, X. Huang, Y. Zhao, "Investigation of the shape, size, angularity and surface texture properties of coarse aggregates", J Constr Build Mater 34:330-336, 2012.

17. EN 1097-8:2009 Tests for mechanical and physical properties of aggregates. Determination of the polished stone value 


\section{LIST OF FIGURES AND TABLES:}

Fig. 1. Aggregates ranking for resistance to polishing based on $S$ values: a) before polishing b) after the $2^{\text {nd }}$ stage

Rys. 1. Ranking odporności kruszyw na polerowanie na podstawie wartości $S$ : a) przed polerowaniem b) po 2 fazie

Fig. 2. Exemplary specimen of the aggregate (gabbro), its surface digital image and its grey level histogram

Rys. 2. Przykładowa próbka kruszywa $\mathrm{z}$ gabra wraz $\mathrm{z}$ obrazem cyfrowym jego powierzchni oraz histogramem wzmocnień

Fig. 3. Summary statistics in particular stages of polishing

Rys. 3. Zestawienie statystyk w poszczególnych fazach polerowania

Fig. 4. Dolomite before polishing

Rys. 4. Dolomit przed polerowaniem

Fig. 5. Gabbro before polishing

Rys. 5. Gabro przed polerowaniem

Fig. 6. Dolomite after $1^{\text {st }}$ polishing

Rys. 6. Dolomit po 1 fazie polerowania

Fig. 7. Gabbro after $1^{\text {st }}$ polishing

Rys. 7. Gabro po 1 fazie polerowania

Fig. 8. Dolomite after $2^{\text {nd }}$ polishing

Rys. 8. Dolomit po 2 fazie polerowania

Fig. 9. Gabbro after $2^{\text {nd }}$ polishing

Rys. 9. Gabro po 2 fazie polerowania

Fig. 10. Image of quartz sandstone before polishing

Rys. 10. Obraz piaskowca kwarcytowego przed polerowaniem

Fig. 11. Image of quartz sandstone after the $2^{\text {nd }}$ stage

Rys. 11. Obraz piaskowca kwarcytowego po 2 fazie polerowania

Fig. 12. Steelmaking slag before polishing - smooth surface

Rys. 12. Żużel stalowniczy przed polerowaniem - gładka powierzchnia

Fig. 13. Steelmaking slag before polishing - roughness surface

Rys. 13. Żużel stalowniczy przed polerowaniem - chropowata powierzchnia

Fig. 14. Steelmaking slag after the $2^{\text {nd }}$ stage - smooth surface with gloss

Rys. 14. Żużel stalowniczy po 2 fazie polerowania - gładka powierzchnia z połyskiem

Fig. 15. Steelmaking slag after the $2^{\text {nd }}$ stage - roughness surface

Rys. 15. Żużel stalowniczy po 2 fazie polerowaniem - chropowata powierzchnia

Tab. 1. Results of the $P S V$ and $S$ values and standard deviation 
Tab. 1. Wyniki $P S V$ i wartości $S$ z odchyleniami standardowymi

Tab. 2. Friedman test results

Tab. 2. Wyniki testu Friedmana

Tab. 3. Percentage change of mean values of the $\sigma_{h}$ parameter in particular stages of polishing

Tab. 3. Procentowe zmiany średnich wartości $\sigma_{h}$ pomiędzy etapami polerowania 


\title{
OCENA ZMIAN MIKROTEKSTURY KRUSZYWA GRUBEGO PODCZAS SYMULOWANEGO POLEROWANIA
}

\author{
W. GARDZIEJCZYK, M. WASILEWSKA
}

Słowa kluczowe: kruszywo grube, mikrotekstura, PSV, analiza obrazu, histogram wzmocnień

\section{STRESZCZENIE:}

W rzeczywistych warunkach ruchu, pod wpływem opon samochodowych, drobnych zanieczyszczeń oraz wody, zachodzi zjawisko polerowania wystających ziaren kruszywa, przyczyniając się do śliskości nawierzchni drogowych. W czasie polerowania ich powierzchnia ulega zmianom w zależności od składu petrograficznego, twardości minerałów, tekstury, struktury, porowatości i stopnia zwietrzenia skały. Miarą odporności na polerowanie kruszywa grubego stosowanego do warstwy ścieralnej nawierzchni drogowych jest wskaźnik polerowalności PSV (Polished Stone Value). $\mathrm{Na}$ jego podstawie trudno jest jednak oceniać zachowanie się kruszywa w procesie polerowania, gdyż wymaga to poznania zjawisk zachodzących na powierzchni poszczególnych ziaren.

$\mathrm{W}$ literaturze są prezentowane różne teorie dotyczące oceny zmian zachodzących na powierzchni ziaren pod działaniem kół pojazdów samochodowych. Opisują one ścieranie się mikroskopijnych protuzji na powierzchni ziarna w powiązaniu z deformacją przestrzenną sieci krystalicznej minerałów. Wraz z rozwojem technologii optoelektronicznej i komputerowej rozwinęly się metody analizy powierzchni bazujące na komputerowym przetwarzaniu obrazów cyfrowych.

Celem artykułu jest ocena zmian mikrotekstury powierzchni ziaren kruszywa grubego $\mathrm{w}$ procesie polerowania w oparciu o obrazy wykonane pod mikroskopem optycznym.

Do badań wytypowano kruszywo dolomitowe, granodiorytowe, gabrowe, polodowcowe, z piaskowca kwarcytowego, z żużla stalowniczego i bazaltowe. Wykonano po cztery próbki analityczne, które polerowano zgodnie z normą PN-EN 1097-8:2009. Proces polerowania trwał 6 godzin z podziałem na I fazę ze ścierniwem korundowym frakcji 300/600 $\mu \mathrm{m}$ i wodą oraz II fazę z proszkiem korundowym frakcji mniejszej od $53 \mu \mathrm{m}$ i wodą. Zarówno przed polerowaniem i po każdej fazie polerowania na każdej próbce w losowo wybranych miejscach wykonywano po 30 obrazów powierzchni ziaren kruszyw pod mikroskopem optycznym w powiększeniu x 3.2. Za miarę mikrotekstury przyjęto wartość odchylenia standardowego $\sigma_{h}$, odczytaną z histogramu wzmocnień dla obrazu cyfrowego badanej powierzchni.

Analiza wyników w oparciu o nieparametryczny test Friedmana wykazała, że istnieją statystycznie istotne różnice pomiędzy średnimi wartościami parametru $\sigma_{h} \mathrm{z}$ histogramów wzmocnień, ustalonymi na tych samych kruszywach w poszczególnych etapach polerowania. Oznacza to, że w procesie polerowania następują istotne zmiany w mikroteksturze na powierzchni kruszywa grubego. Są one uzależnione od charakterystyki petrograficznej skały z której kruszywo zostało wyprodukowane. Ważną rolę odgrywa przy tym twardość minerałów. Wykazano, że kruszywa wyprodukowane ze skał, które są zbudowane z minerałów o zbliżonej twardości (dolomit, granodioryt) lub skał o strukturze skrytokrystalicznej (bazalt) bardzo łatwo poddają się czynnikom polerującym. Na ich powierzchni dochodzi 
do istotnej deformacji sieci krystalograficznej już w I fazie oznaczenia (przy użyciu grubego ścierniwa i wody). Natomiast powierzchnia kruszywa zbudowanego ze skały o zróżnicowanej twardości minerałów (gabro) pod wpływem grubego ścierniwa i wody ulega jedynie ścieraniu. Dopiero materiały polerujące takie, jak: mączka korundowa i woda, dozowane w II fazie, przyczyniają się do deformacji sieci krystalograficznej niektórych obszarów minerałów.

Na podstawie analizy obrazów udowodniono, że piaskowiec kwarcytowy i żużel stalowniczy mają zdolności do regeneracji mikrotekstury podczas symulacji procesu polerowania. Takie kruszywa są szczególnie pożądane do zastosowania do warstwy ścieralnej w obszarach takich, jak: skrzyżowania, łącznice drogowe, pasy włączeń i wyłączeń. Wyniki badań potwierdziły, że z punktu widzenia odporności na polerowanie bardzo dobrym materiałem są kruszywa z piaskowca kwarcytowego, ̇̇użla stalowniczego oraz gabra, a gorszym materiałem - kruszywa $\mathrm{z}$ dolomitu i granodiorytu. 